Jpn. J. Oral. Biol., $27:$ 146-151, 1985.

\title{
ラット切歯歯骾細胞の培養条件に関する研究
}

\author{
春日井昇平 佐藤 温 重* 小椋秀 亮 \\ 東京医科歯科大学歯学部歯科薬理学教室 (主任教授: 小椋秀亮) \\ *東京医科歯科大学歯学部第 2 理工学教室（主任教授：佐藤温重）
}

〔受付：昭和59年 9 月 20 日〕

\section{A study on the optimal medium for culturing of rat incisal pulp cells}

\author{
Shohei Kasugai, Atsushige Sato* Hideaki Ogura \\ Department of Pharmacology, Faculty of Dentistry, \\ Tokyo Medical and Dental University \\ (Director: Prof. Hideaki Ogura) \\ *Department of Dental Technology, Faculty of Dentistry, \\ Tokyo Medical and Dental University \\ Yushima 1-5-45, Bunkyo-ku, Tokyo 113 \\ (Director: Prof. Atsushige Sato)
}

[Accepted for publication: September 20, 1984]

Key words : dental pulp cells / culture condition/chemically defined medium/serum concentration

\begin{abstract}
The present study was carried out to establish the culture condition, namely, which chemically defined medium (F 12, Eagle's basal medium, minimum essential medium, Dulbecco's modified Eagle's medium, RPMI 1640, 199), what kind of serum (calf serum, fetal calf serum) and which concentration of the serum are the most adequate to increase rat ircisal pulp cells. The area occuqied by outgrowth cells and maximum cell density were measured by using the explant culture technique. Following subculture, cell counting estimation was performed in some cases. The present results suggest that minimum essential medium supplemented with 15 per cent of fetal calf serum is the most adequate to increase of the incisal pulp cells in culture.
\end{abstract}

\section{緒 言}

歯髄細胞の培養は，歯髄組織の生物学的特性, とくに歯髄細胞の象牙芽細胞への分化をめぐる研 究にとって有用な手段の一つと考えられる。歯髄 片を培養器の底面に置くと多数の細胞が歯髄片よ り遊出してくることが報告されている ${ }^{1-14)}$ 。また, 歯髄組織をタンパク分解酵素を用いて分散して, その細胞を培養する方法も広く行われている ${ }^{20)}$ 。近年培養技術の進歩とともに, 多くの種類の 合成培地が考案され, 市販の合成培地に血清を加 えた培地を使用することによりほとんどの組織細 胞の初代培養が可能となっている。歯髄細胞の培

東京都文京区湯島 1-5-45 (广 113)
養は前述の如く多数報告されているが，培地，血 清等の培養条件に関する報告は少ない(15-17)。われ われは以前よりラット切歯歯髄を用いて歯髄細胞 に関する研究を進めて来たが ${ }^{13,14)}$ ，今回ラット切 歯歯髄細胞の培養条件に関する検討を行ったの で，その結果を報告する。

\section{材料および方法}

実験には生後 7 週齢平均体重 $180 \mathrm{~g}$ の雄性 Wistar 系ラットを用いた。

歯髄片の摘出および培養は下記の方法により行 った。

エーテル麻酔下で断頭屠殺後両側の上顎切歯を 摘出し稀ヨードチンキにて消毒した。歯胚部の硬 


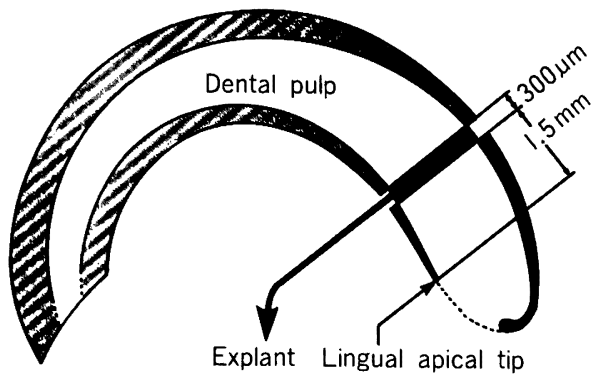

Fig. 1 The explant was dissected out from the same region of the upper incisal pulp in rat.

組織を鋭利なピンセットにて除き，滅菌ガーゼに て歯髄を注意深くひきぬいた。歯髄を streptomycin $200 \mu \mathrm{g} / \mathrm{m} l$, penicillin $\mathrm{G} 200 \mathrm{IU} / \mathrm{m} l$ を含む滅菌 Hanks 平衡塩類溶液にて洗い, 実体顕 微鏡下で Fig. 1 に示される一定部位より歯髄片を切り出し た。培養用プラスチックフラスコ（Falcon, $25 \mathrm{~cm}^{2}$ Flask）の底面に 4 個の歯髄片を置き $5 \mathrm{ml}$ の各種 培地を加えた。各培地とも streptomycin $100 \mu \mathrm{g} /$ $\mathrm{m} l$, penicillin $\mathrm{G} 100 \mathrm{IU} / \mathrm{m} l$ を添加し, 適量の $\mathrm{NaHCO}_{3}$ を加えたのち, 実験 I， II においては 1 $\% \mathrm{CO}_{2} 99 \%$ 空気の気相下で，また実験而におい ては密栓したのち, $37^{\circ} \mathrm{C}$ において $\mathrm{pH} 7.4$ に保っ た。実験 I，II において培養 3 日に半液交換し， その後 3 日毎に全液交換を行った。

（実験 I ）各種血清濃度が 歯髄片からの 遊出細 胞に及ぼす影響

培地はF 12 （日水）を使用し，各種濃度（v/v \%) の血清を添加した。すなわち牛胎児血清（Flow Laboratories, Lot No. 29101839, 以下 FCS と略す）については $2,5,10,15,20 \%$ 添加, 牛血 清 (Flow Laboratories, Lot No. 29131813, 以下 CS と略す) は $5,10,15,20 \%$ 添加, 及び血清無 添加培地を使用した。遊出細胞の出現時期, 及び 遊出細胞の形態は 位相差顕微鏡下で観察した。培 養開始より20日後に各歯髄片からの遊出細胞の周 囲を位相差顕微鏡に連動したペンタグラフにより 写しとり，プラニメーターにより遊出細胞の占め る面積を測定した。

（実験 II） $15 \%$ FCS 添加各種培地, 及びニワト リ胚抽出液 (chick embryo extract, 以下 CEE と 略す） 添加が歯髄片からの遊出細胞に及ぼす影響
F12, Eagle's basal medium (BME), Minimum essential medium (MEM), Dulbecco's modified Eagle's medium (DMEM), RPMI $1640 ， 199$ (いずれも日水製) に FCS 15\%添加し た培地を使用した。また通法により CEE を作製 し ${ }^{21}$ ， F 12に FCS 15\%，CEE $5 \%$ を添加した 培地も用いた。位相差顕微鏡下に遊出細胞を観察 するとともに，実験 I と同様に培養20日後に遊出 細胞の占める面積を測定した。また遊出細胞のも っとも細胞密度の高いと思われる部位 3 ケ所にお いて位相差顕微鏡下で細胞密度を計測し，その最 高值をもって最高細胞密度とした。

（実験III）MEM 及び DMEM に添加する FCS の最適濃度を求める実験

FCS 15\%添加 MEM, または FCS 15\%添加 DMEM を用いて, 初代培養を30日間行った。そ の後, $\mathrm{Ca}, \mathrm{Mg}$-free phosphate buffered solution にて遊出細胞を洗い， 0.5\% trypsin (Difco, 1 : $250), 0.02 \% \mathrm{EDTA} \cdot 2 \mathrm{Na}$ (和光) を含む $4{ }^{\circ} \mathrm{C}$ の $\mathrm{Ca}, \mathrm{Mg}$-free phosphate buffered solution 5 分間作用させた。その後 trypsin EDTA 液を除 き, 次いで FCS 15\%添加 MEM または FCS 15\%添加 DMEM を加え pipetting を行い細胞を dish より分離した。そして遠沈管にうつし， 1500 $\mathrm{rpm}$ にて遠沈し， 細胞数が $10^{4} / \mathrm{m} l$ となるように MEM または DMEM にて稀釈したのち, 試験管 に250 $\mu l$ ゔつ分注した (2,500cells/tube)。その 後, FCS 5, 10，15，20\%添加 MEM または $\mathrm{DMEM}$ を $1 \mathrm{ml}$ 加え密栓して培養を行った。培地 の交換は 2 日毎に行い, 培養10日後に crystal violet 染色を施し細胞数を計測した ${ }^{21}$ 。

\section{実験 結果}

（実験 1 ）各種血清濃度が 歯髄片からの 遊出細 胞に及ぼす影響について

無血清培地（F12培地単独）では遊出細胞の出 現は認められなかった。また, Fig. 2, 3 に示され るごとく FCS, CS とも濃度が下がると培養開始 より遊出細胞出現までの時間が延長した。しか し，位相差顕微鏡下において血清の濃度による遊 出細胞の形態変化は認められなかった。培養初期 に出現する細胞は突起を持った線維芽細胞様形態 


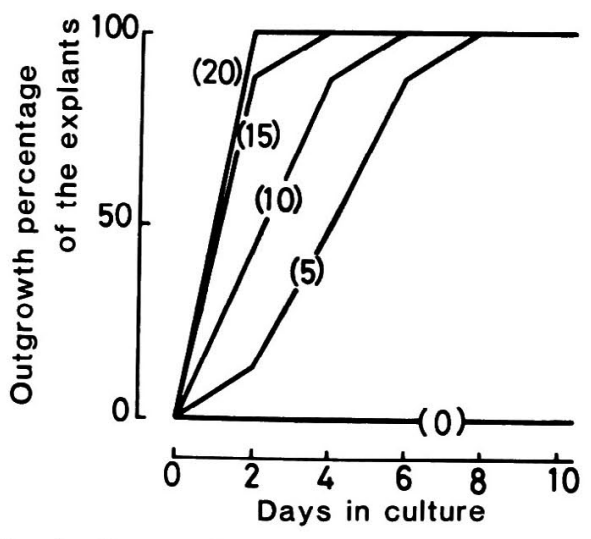

Fig. 2 Outgrowth percentage of the explants. Concentrations of calf serum were indicated in parentheses.

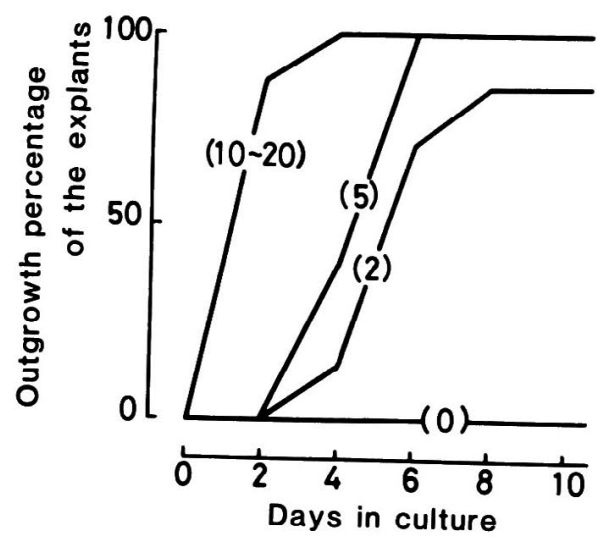

Fig. 3 Outgrowth percentage of the explants. Concentrations of fetal calf serum were indicated in parentheses.

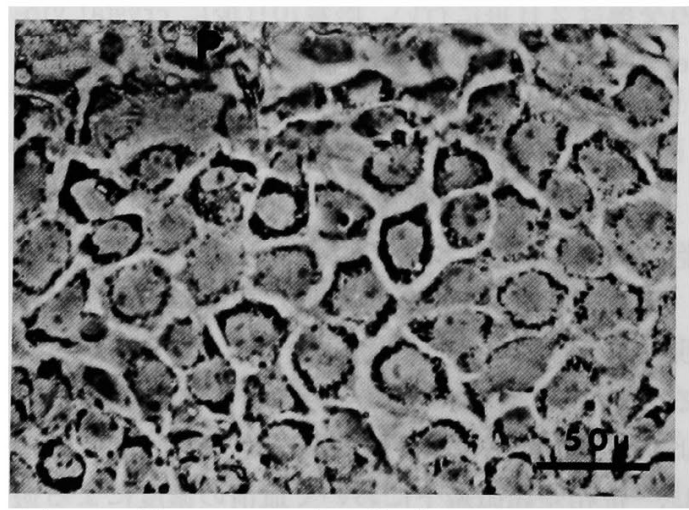

Fig. 4 The outgrowth cells from the pulp explant $(\mathrm{P})$ after 10 days in culture under phase contrast microscope.

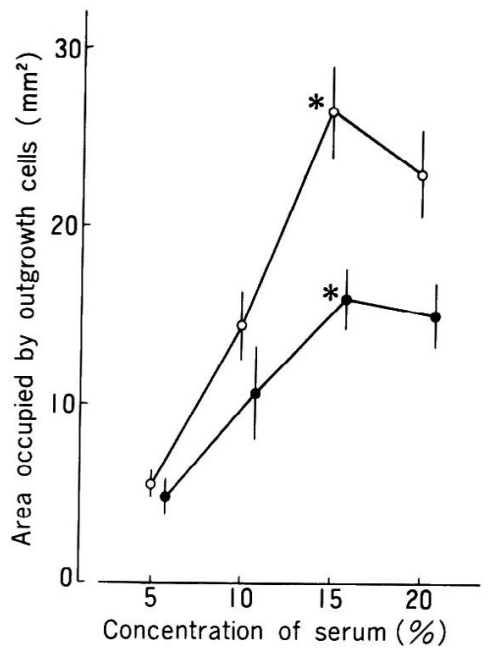

Fig. 5 The area of the outgrowth cells from the pulp explant after 20 days in culture. The culture medium was F12 supplemented with various concentrations of calf serum (๑) or fetal calf serum (O). Each point and bar represents the mean $\pm \mathrm{SD}(\mathrm{n}=8)$. *Significantly different each other $(p<0.005)$.

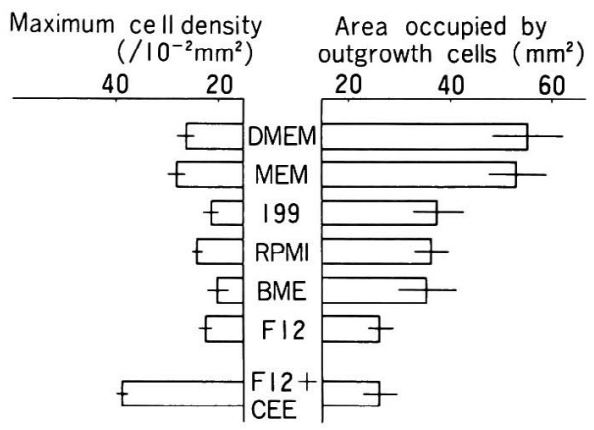

Fig. 6 The area of the outgrowth cells from the pulp explant and maximum cell dersity after 20 days in culture. Various chemically defined mediums supplemented with 15 per cent of fetal calf serum were used. Each column and bar represents the mean $\pm \operatorname{SD}(n=8)$. The area of the outgrowth cells was maximum in DMEM or MEM and not significantly different each other $(\mathrm{p}>0.5)$.

を示す細胞であるが， 細胞密度が増加するにつれ て多角形様で核が大きく，原形質顆粒を多数含む 上皮細胞様形態を示すようになった (Fig. 4)。培 羕20日後の遊出細胞が占める面積を比較すると, 


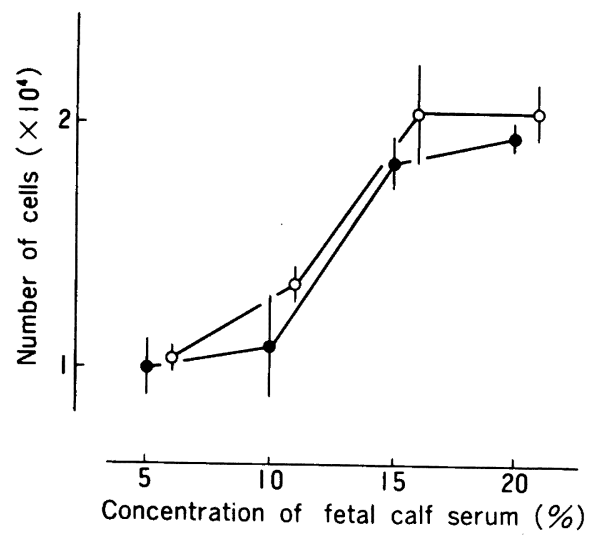

Fig. 7 Relation between number of cells and concentration of fetal calf serum. Follo. wing subculture with trypsin-EDTA solution, 2,500 cells were inoculated and after 10 days cells were counted. Culture medium was MEM (๑) or DMEM (O) supplemented with various concentrations of fetal calf serum. Each point and bar represents the mean $\pm \operatorname{SD}(n=4)$.

同一濃度においては FCS の方が CS より面積が 大きく，FCS，CS ともに15\%において最大面積 を示した (Fig. 5)。

（実験 II ） $15 \%$ FCS 添加各種培地, 及び CEE 添加が歯髄片からの遊出細胞に及ぼす影響

15\% FCS 添加において培地の種類にかかわら ず培養 2 日後にすべての歯髄片から遊出細胞が 出 現した。また CEE 添加の場合も同様に培養 2 日 後に遊出細胞が出現した。培地の種類によって遊 出細胞の形態的差異は認められなかった。

Fig. 6 に示したように, 培養20日後に遊出細胞 の占める面積は DMEM, MEM が最も大きく両 者の間には有意な差が認められなかった（P> 0.5)。また細胞密度についても DMEM, MEM 両者の間に有意な差は認められなかった。一方, F12について CEE の影響を調べたところ， CEE 添加により著明な細胞密度の上昇現象が 観察され た。

（実験III）MEM，DMEM に添加する FCS の 最適濃度について

Fig. 7 に示したように, MEM, DMEM ともに FCS の添加濃度を增すにつれて 10日間培養後の 細胞数は増すが，15\%でほぼ極大に達することが
確かめられた。FCS 15\%添加において MEM, DMEM 両者間に有意な差は認められなかった。

\section{考察および結論}

実験 Iより無血清培地（F 12単独）では歯髄片 から細胞が遊出せず，遊出するには血清が必要で あることが示された（Fig．2，3）。このことは血 清中に Fibronectin と呼ばれる ${ }^{22}$ 細胞の移動 (migration) ${ }^{23)}$ ，付着伸展 (attachment and spreading $)^{24)}$ に必要な高分子タンパクが含まれている ことにより説明できるのではないかと考えられ る。その他にも，血清中には細胞増殖に必要な未 知の成分が含まれており，近年血小板由来成長因 子 ${ }^{25}$ その他の各種の成長因子，および多くの種類 のホルモン ${ }^{26)}$ の存在が確かめられている。歯髄細 胞に関してもある種の成長因子による増殖に及ほ 寸影響について報告されている ${ }^{19 !}$ 。しかし特殊な 例を除き，一般に初代培養において細胞を増殖さ せる場合には，血清を加えた合成培地を用いなく

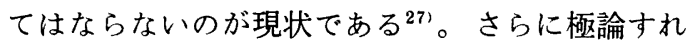
ば，現在市販されている培地そのものは細胞を増 殖させる能力を欠いており，むしろ培地に添加さ れている血清が 細胞を増殖させていると見なすべ きで, 在来の培地はその補助的役割を果すに過ぎ ないとも言える ${ }^{28)}$ 。今回の研究は，培養下におい て歯髄細胞の増殖に最も適切な条件を決定する目 的で，諸種の細胞増殖因子が含まれている血清と 合成培地の組合せについて検索を行った。

本研究においては，培養20日後の遊出細胞の占 める面積を指標として，歯稢細胞の増殖に及ぼす 培地の種類, 血清の影響を検索したが，この面積 測定による方法は簡便ではあるが，必ずしも最良 の評価法とはいえない点がある。それは, 細胞数 が増加しなくとも，細胞密度が粗となることによ り遊出細胞の占める面積が増加する可能性がある

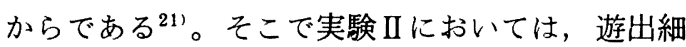
胞の占める面積を測定すると同時に 最高細胞密度 を測定し，両測定結果を総合して評価することを 試みた。その結果, 合成培地と FCS 15\%の組み 合わせでは, MEM, DMEM が最も歯髄細胞の増 殖に対して良い結果を示した（Fig. 6)。CEE は 古くから培養液に添加され用いられているが，こ 
れは著明な細胞密度の上昇を引き起こすことから 推定して (Fig. 6), 細胞の増殖にとって有効な成 分を含んでいるものと考えられる。今回は, MEM または DMEM に FCS を15\%添加し,さ らにCEE を加えた組合せについての実験は行わ なかったが，血清のみの添加でも充分な細胞増 殖が期待できる結果が得られた。したがって，今 後の培養手段を簡略化する意味からも，血清と $\mathrm{CEE}$ の組合せを検討することは省略することに した。

われわれは以前 F 12培地を用いて実験を行って 来たが13-15)，これ以外の培地として, $\mathrm{BME}^{10,11)}$,

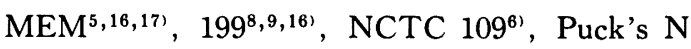
$16^{16)}$ ，McCoy's 5A ${ }^{16)}$ 等も用いられている。また 最近は DMEM に FCS を添加した培地が用いら

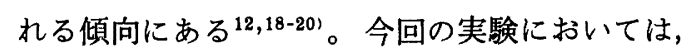
面積測定法だけでなく，細胞数算定法による測定 結果でも FCS 15\%を添加した場合 MEM, DM$\mathrm{EM}$ の両者の間に差は認められなかった（Fig. 7)。DMEM はMEM に含まれるアミノ酸を約 2 倍, ビタミン類を約 4 倍量にし, さらに非必須ア ミノ酸が加えられている ${ }^{29)}$ 。その結果, DMEM は溶液のまま長期保存すると培地の成分が 析出す

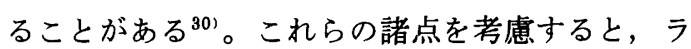
ット切歯歯髄細胞の培養には MEM に FCS 15 \%添加した培地が最も利用価值が高いものと考え られる。

謝辞：本研究は文部省科学研究費 (No. 58440070) の 補助を受けた。また本研究の要旨は第16回口腔組織培養 研究会に㧍いて発表した。

抄録：本研究は, ラット切歯歯髄細胞の培養にとって最も適する培地を決定する目的で行われた。用いた 合成培地は F12, Eagle's basal medium (BME), minimum essential medium (MEM), Dulbecco's modified Eagle's medium (DMEM), RPMI 1640, 199 であり, 血清は牛血清 (CS) と牛胎児血清 (FCS) を用いた。歯咀片から遊出した細胞の占める面積を測定する方法, および細胞数の算定法により評価した。 その結果, ラット切歯歯髄細胞の培羡にとって, MEM に FCS を15\%添加した培地が最も適していること が示唆された。

\section{文献}

1) Pinkerton, H. and Boyle, P: Cultivation in vitro of tissues from enamel organ and dental pulp. J. Dent. Res. 15 : 221, 1935.

2) Szabo, G.: Studies on the cultivation of teeth in vitro. J. Anat. 88: 31-44, 1954.

3) Niizima, M. and Cattoni, M. : Dental papilla in tissue culture. J. Dent. Res. 37 : 767$779,1958$.

4) Zussman, W. V. and Ioachim, H. L.: Growth of odontoblasts in vitro. Lab. Invest. $13: 371-377,1964$.

5）池尻 茂, 中島嘉助：ヒトおよびマウスの歯髅 と象牙芽細胞の培養に関する研究. 九州歯会誌 $22: 32-36,1968$.

6) Pourtois, $M$ : Étude de la différenciation des odontoblastes en culture in vitro. Arch. Biol. 77 : 107-137, 1966.

7) Vidic, B., Chen, R. and Taylor, J. J. : Functional behavior and structural modification of pulpal fibroblasts cultured in vitro. Arch. Anat. Hist. Embr. Norm. et Exp. 55 : 51-73, 1972.

8）内海順夫, 武田鈴子：歯髄組織（細胞）の in vitroにおける動態. 城歯大紀要 $1: 85-88$,
1972.

9) Kawahara, H., Imanishi, Y. and Nishida, $\mathrm{T}$ : A new cell strain derived from human dental pulp. 国際歯科ジャーナル. 4: 767768, 1976.

10) Magloire, H. and Joffre, A : Fine structural observations of calcium storage in human dental pulp cells in primary culture. J. Biol. Buccale. 7 : 307-320, 1979.

11) Magloire, H., Joffre, A., Grimaud, J. A., Herbage, D., Couble, M. L., Chavrier, C. and Dumont, J.: Synthesis of type I collagen by human odontoblast-like cells in explant culture: Light and electron microscope immunotyping. Cell. Mol. Biol. 27 : 429-435, 1981.

12) Prime, S. S. and Reade, P. C. : The separation and culture of cell populations from bovine molar tooth germs. Archs. Oral Biol. 25 : 187-193, 1980.

13）小椋秀亮, 春日井昇平, 佐藤温重 : ${ }^{3} \mathrm{H}$-thymidine autoradiography を応用した in vitro におけるラット切歯歯髄細胞の動態に関する研 究. 歯基礎誌 $23: 211,1981$.

14) Kasugai, S: Autoradiographic study using ${ }^{3} \mathrm{H}$-thymidine on rat incisal pulp cells in 
vitro. Bull. Tokyo Med. Dent. Univ. 30 : 9-15, 1983.

15）佐藤温重, 小沢和子：家鬼切歯歯胚由来細胞の 培美に関する研究 I, 歯科基礎誌 $17: 188$ 193, 1975.

16) Miller, W. A., Everett, M. M. and Cramer, J. F.: Growth of bovine pulp cells in monolayer culture. J. Endodon. 12 : 385-389, 1976.

17）堀越 勝, 名倉英明，木村義孝，小山弘治，伊 藤秀夫 : ラット胎児の歯胚由来細胞 (RTG) の樹立. 口病誌 $46: 211-219,1979$.

18) Gotoh, Y., Saito, S. and Sato, A.: Synthesis of procollagen by odontogenic cells of rabbit tooth germs. Biochim. Biophys. Acta 587 : 253-262, 1979.

19) Steidler, N. E. and Reade, P. C. : Epidermal growth factor and proliferation of odontogenic cells in culture. J. Dent. Res. 60 : 1977-1982, 1981.

20) Shuttleworth, C. A., Berry, L. and Wilson, N. : Collagen synthetized in rabbit dental pulp fibroblast cultures. Archs. Oral Biol. 25 : 201-205, 1980.

21）黒田行昭, 動物組織培養法, 共立出版, 東京,
1974.

22) Yamada, K. M. and Olden, K. : Fibronectinseadhesive glycoproteins of cell surface and blood. Nature 275 : 179-184, 1978.

23) Bürk, R. R. : A factor from a transformed cell line that affects cell migration. Proc. Nat. Acad. Sci. USA 70 : 369-372, 1973.

24) Grinnell, F.: Cell spreading factor. Exp. Cell Res. 102 : 51-62, 1976.

25) Antoniades, H. N. and Scher, C. D.: Radioimmunoassay of a human serum growth factor for Balb/c-3 T 3 cells : derivation from platelets. Proc. Natl. Acad. Sci. USA 74 : 1973-1977, 1977.

26) Hayashi, I., Larner, J. and Sato, G. : Hormonal growth control of cells in culture. In Vitro. 14 : 23-30, 1978.

27) Adams, R. L. P.: Cell Culture for Biochemists. Elsevier, Amsterdam. 1980.

28）山根 績: 組織培養培地 $の$ 生産化, 組織培養 7 : 275-277, 1981.

29）中家 茂 : 組織培養培地の製造と各種培地の特 色. 組織培養 $7: 293-295,1981$.

30）小林信人, 高瀬譲治 : 組織培養用培地の動向に ついて. 組織培養 $7: 278-280,1981$. 